\title{
ANALISIS FAKTOR-FAKTOR YANG MEMPENGARUHI PENDAPATAN USAHATANI PADI SAWAH DI KECAMATAN CAWAS KABUPATEN KLATEN
}

\author{
Duwi Wulansari, Minar Ferichani, Rr. Aulia Qonita \\ Program Studi Agribisnis, Fakultas Pertanian, Universitas Sebelas Maret Surakarta \\ Jalan Ir. Sutami No.36 A Kentingan Surakarta 57126 Telp./Fax (0271) 637457 \\ E-mail :wulansariduwi@student.uns.ac.id
}

\begin{abstract}
The aims of this study were to know the cost and the income of rice field farming and to analyze the influence factors in the income of rice field farming in Cawas, Klaten. The basic method that used in this study was descriptive analytics method. The study area was determined by purposive. It was done by considering the study area that had the largest rice field in Klaten. The data were collected using primary and secondary data. The result showed that: the cost commercializes of the rice field farming were used by the farmer was $R p$ 14.543.253/Ha, the revenue were accepted by the farmer was Rp 22.814.234/Ha, and the income that accepted by the farmer was $R p$ 8.270.981/Ha every season. The factors that influence to the income of rice field farming in Cawas, Klaten were labor productivity, pesticide cost, selling price, land productivity, and tractor cost. Other factors tested were age, education, experience, the number of family burden, fertilizer cost, the number of family members active in farming, and type of irrigation did not significant affected to the rice field farming income in Cawas, Klaten.
\end{abstract}

Keywords : Factor Analysis, Rice, Income, Regression, Farming

\begin{abstract}
Abstrak : Penelitian ini bertujuan untuk mengetahui biaya dan pendapatan usahatani padi sawah, serta mengetahui faktor-faktor yang mempengaruhi pendapatan usahatani padi sawah di Kecamatan Cawas Kabupaten Klaten. Metode dasar penelitian yang digunakan adalah metode deskripsi analitis. Penentuan lokasi penelitian dilakukan secara purposive dengan pertimbangan bahwa daerah penelitian memiliki luas lahan sawah terbesar di Kabupaten Klaten. Data yang digunakan adalah data primer dan sekunder. Hasil penelitian ini menunjukkan bahwa biaya mengusahakan usahatani padi sawah adalah $\mathrm{Rp}$ 14.543.253/Ha, penerimaan yang diterima petani $\mathrm{Rp}$ 22.814.234/Ha, dan pendapatan Rp 8.270.981/Ha per musim tanam. Faktor yang mempengaruhi pendapatan usahatani padi sawah di Kecamatan Cawas, Kabupaten Klaten adalah produktivitas tenaga kerja, biaya pestisida, harga jual, produktivitas lahan, dan biaya traktor. Faktor lain yang diuji yaitu umur, pendidikan, pengalaman, jumlah tanggungan keluarga, biaya pupuk, jumlah anggota keluarga yang aktif usahatani dan jenis irigasi tidak berpengaruh nyata terhadap pendapatan usahatani padi sawah di Kecamatan Cawas Kabupaten Klaten.
\end{abstract}

Kata kunci : Analisis Faktor, Padi, Pendapatan, Regresi, Usahatani

\section{PENDAHULUAN}

Indonesia merupakan negara yang kaya akan sumber daya alam, termasuk tanaman pangan, buah-buahan, dan sayuran. Tanaman pangan merupakan tanaman utama yang dikonsumsi manusia sebagai makanan untuk memberikan asupan energi bagi tubuh. Pertanian merupakan sektor penting penyedia pangan masyarakat Indonesia. Sektor pertanian terbentuk atas lima subsektor yaitu subsektor tanaman pangan, tanaman perkebunan, kehutanan, peternakan, dan perikanan. Menurut Rahim (2007), pertanian merupakan kegiatan dalam usaha mengembangkan tumbuhan dan hewan supaya tumbuh lebih baik untuk memenuhi 
kebutuhan manusia, misalnya bercocok tanam, beternak, dan melaut. Pertanian juga sebagai jenis usaha atau kegiatan ekonomi berupa penanaman tanaman atau usahatani (pangan, holtikultura, perkebunan, dan kehutanan), peternakan dan perikanan.

Padi (Oryza sativa L.) merupakan salah satu tanaman budidaya terpenting dalam peradaban manusia. Padi sudah dikenal sebagai tanaman pangan sejak jaman prasejarah (Purnamaningsih, 2006). Tanaman padi terdiri dari dua jenis yaitu padi sawah dan padi ladang. Padi sawah adalah padi yang ditanam di tanah sawah, sedangkan padi ladang merupakan padi yang ditanam di ladang atau tanah kering.

Usahatani merupakan suatu usaha dengan memanfaatkan sumberdaya alam, tenaga kerja, dan modal untuk mendapatkan pendapatan yang dilakukan oleh petani. Menurut Lumintang (2013), besar kecilnya pendapatan usahatani padi sawah yang diterima oleh penduduk di desa dipengaruhi oleh penerimaan dan biaya produksi. Jika produksi dan harga jual padi sawah semakin tinggi maka akan meningkatkan penerimaan. Apabila biaya produksi lebih tinggi dari penerimaan maka akan menyebabkan kerugian usaha para petani. Analisis usahatani sangat diperlukan dalam menjalankan usaha, hal ini guna mengetahui apakah usahatani yang dijalankan memberikan keuntungan atau tidak.

Pendapatan merupakan salah satu indikator untuk mengukur kesejahteraan seseorang atau masyarakat, sehingga pendapatan masyarakat ini mencerminkan kemajuan ekonomi suatu masyarakat. Menurut Sukirno (2000), pendapatan individu merupakan pendapatan yang diterima seluruh rumah tangga dalam perekonomian dari pembayaran atas penggunaan faktor-faktor produksi yang dimilikinya dan dari sumber lain.

Tingkat kesejahteraan petani sering dikaitkan dengan keadaan usahatani yang dicerminkan oleh tingkat pendapatan petani. Tingkat pendapatan ini dipengaruhi oleh banyak faktor, seperti faktor sosial, ekonomis, dan agronomis. Salah satu faktor tersebut yang tidak kalah pentingnya adalah penggunaan faktor produksi yang dihasilkan (Nababan, 2009). Tingkat pendapatan petani dipengaruhi oleh berbagai macam faktor, oleh karena itu perlu adanya analisis lebih lanjut terkait dengan faktor-faktor yang mempengaruhi pendapatan usahatani padi sawah di Kecamatan Cawas Kabupaten Klaten.

Penelitian ini bertujuan untuk mengetahui biaya dan pendapatan usahatani padi sawah, serta mengetahui faktor-faktor yang mempengaruhi pendapatan usahatani padi sawah di Kecamatan Cawas Kabupaten Klaten.

\section{METODE PENELITIAN}

Metode dasar penelitian yang digunakan adalah metode deskripsi analisis dengan teknik survei. Penelitian ini dilakukan pada bulan Februari 2017. Penentuan lokasi penelitian dilakukan secara purposive dengan pertimbangan bahwa Kecamatan Cawas memiliki luas lahan sawah terbesar di Kabupaten Klaten. Data yang digunakan adalah data primer dan sekunder. Teknik pengumpulan data dilakukan dengan wawancara, observasi, dan dokumentasi

Pengairan lahan sawah di Kecamatan Cawas terdiri dari 3 jenis yaitu irigasi teknis, semi teknis dan tadah hujan. Berdasarkan kondisi tersebut, maka sampel yang digunakan adalah 3 desa yang mewakili dari ketiga jenis irigasi tersebut dengan luas lahan terbesar dan jumlah petani paling banyak, yaitu Desa Karangasem, Desa Pakisan, dan Desa Gombang. Penelitian ini menggunakan sampel sebanyak 30 orang diambil dari Desa Karangasem, Desa Pakisan dan Desa Gombang.

Analisis Biaya Mengusahakan Usahatani Padi Sawah dilakukan dengan menggunakan rumus:

Biaya mengusahakan = Biaya alat-alat luar + Upah Tenaga Kerja Keluarga..

Analisis Penerimaan Usahatani Padi Sawah dilakukan dengan menggunakan rumus:

$\mathrm{TR}=\mathrm{Y} \times \mathrm{Py}$

Keterangan :

TR :Total Penerimaan Usahatani Padi

Sawah (Rupiah)

Y : Jumlah Produksi (Kg)

Py : Harga produk (Rupiah)

(Suratiyah, 2015).

Pendapatan Bersih Usahatani Padi Sawah dihitung denganrumus: $\mathrm{Pd}=\mathrm{TR}-\mathrm{Bm}$. 
Keterangan :

$\mathrm{Pd}:$ Pendapatan Usahatani (Rp/Ha/MT)

TR : Penerimaan Usahatani $(\mathrm{Rp} / \mathrm{Ha} / \mathrm{MT})$

Bm: Biaya Mengusahakan (Rp/Ha/MT)

Untuk mengkaji faktor-faktor yang mempengaruhi pendapatan usahatani padi sawah di Kecamatan Cawas Kabupaten Klaten digunakan model regresi linier berganda sebagai berikut:

$$
\begin{aligned}
& Y=a+b_{1} X_{1}+b_{2} X_{2}+b_{3} X_{3}+b_{4} X_{4}+b_{5} X_{5}+ \\
& b_{6} X_{6}+b_{7} X_{7+} b_{8} X_{8}+b_{9} X_{9}+b_{10} X_{10}+b_{11} X_{11}+ \\
& b_{1} D_{1}+\mu \ldots \ldots \ldots \ldots \ldots \ldots \ldots \ldots \ldots \ldots \ldots \ldots \ldots \ldots \ldots \ldots \ldots \ldots
\end{aligned}
$$

Keterangan :

Y : Pendapatan Usahatani Padi Sawah

(Rupiah)

$\mathrm{X}_{1}$ : Umur (Tahun)

$\mathrm{X}_{2}$ : Pendidikan (Th)

$\mathrm{X}_{3}$ : Pengalaman $(\mathrm{Th})$

$\mathrm{X}_{4}$ : Jumlah Tanggungan

Keluarga (Orang)

$\mathrm{X}_{5}$ : Produktivitas Tenaga

Kerja $(\mathrm{Kg} / \mathrm{HKP})$

$\mathrm{X}_{6}$ : Biaya Pupuk (Rupiah)

$\mathrm{X}_{7}$ : Biaya Pestisida (Rupiah)

$\mathrm{X}_{8}$ : Harga Jual (Rupiah/Kg)

$\mathrm{X}_{9}$ : Jumlah Anggota Keluarga

Yang Aktif Usahatani

(Orang)

$\mathrm{X}_{10}$ : Produktivitas Lahan

$(\mathrm{Kg} / \mathrm{Ha})$

$\mathrm{X}_{11}$ : Biaya Traktor (Rupiah)

$\mathrm{D}_{1}$ : Dummy jenis irigasi

$$
\begin{aligned}
& 1 \text { : Teknis } \\
& 0: \text { Lainnya } \\
& \mu \quad \text { : error term }
\end{aligned}
$$

Hipotesis tentang faktor-faktor yang mempengaruhi pendapatan diformulasikan sebagai berikut:

$\mathrm{H}_{0}: \beta \mathrm{i}=0$

$\mathrm{H}_{1}$ : minimal salah satu $\beta \mathrm{i} \neq 0$,

dengan kriteria pengambilan keputusan :

Jika $\mathrm{F}$ hitung $>\mathrm{F}$ tabel, maka $\mathrm{H}_{0}$ ditolak dan $\mathrm{H}_{1}$ diterima berarti faktor-faktor berupa umur, pendidikan, pengalaman, jumlah tanggungan keluarga, produktivitas tenaga kerja, biaya pupuk, biaya pestisida, harga jual, jumlah anggota keluarga yang aktif usahatani, produktivitas lahan, biaya traktor, dan jenis irigasi secara bersama-sama berpengaruh terhadap pendapatan usahatani padi sawah.

Jika $\mathrm{F}$ hitung $\leq \mathrm{F}$ tabel, maka $\mathrm{H}_{0}$ diterima dan $\mathrm{H}_{1}$ ditolak, berarti faktor-faktor berupa umur, pendidikan, pengalaman, jumlah tanggungan keluarga, produktivitas tenaga kerja, biaya pupuk, biaya pestisida, harga jual, jumlah anggota keluarga yang aktif usahatani, produktivitas lahan, biaya traktor, dan jenis irigasisecara bersama-sama tidak berpengaruh nyata terhadap pendapatan usahatani padi sawah.

Keberartian Koefisien regesri (Uji t) diuji dilakukan dengan formula hipotesis:

$\mathrm{H}_{0}: \beta_{\mathrm{i}}=0$

$\mathrm{H}_{1}: \beta_{\mathrm{i}} \neq 0$,

dengan kriteria pengambilan keputusan :

Jika $t_{\text {hitung }}>t_{\text {tabel }}$ maka $\mathrm{H}_{0}$ ditolak dan $\mathrm{H}_{1}$ diterima berarti faktor ke-i $\left(\mathrm{X}_{\mathrm{i}}\right)$ secara individu berpengaruh nyata terhadap pendapatan usahatani padi sawah.

Jika $t_{\text {hitung }} \leq \mathrm{t}_{\text {tabel, }}$ maka $\mathrm{H}_{0}$ diterima dan $\mathrm{H}_{1}$ ditolak berarti faktor ke-i $\left(\mathrm{X}_{\mathrm{i}}\right)$ secara individu tidak berpengaruh nyata terhadap pendapatan usahatani padi sawah.

\section{HASIL DAN PEMBAHASAN}

\section{Identitas Petani Responden}

Umur petani responden di Kecamatan Cawas Kabupaten Klaten paling banyak adalah petani dalam usia produktif (15-64 tahun) dengan jumlah petani 19 orang. Kelompok petani usia non produktif (65 tahun ke atas) sebanyak 11 orang. Tingkat pendidikan petani padi sawah paling banyak adalah SD dengan jumlah sebanyak 12 orang. Petani yang tidak menempuh pendidikan formal (tidak sekolah) sebanyak 7 orang. Petani dengan tingkat pendidikan SMA sebanyak 7 orang. Petani responden dengan tingkat pendidikan SMP sebanyak 4 orang. Rata-rata pengalaman mengusahakan padi sawah petani responden adalah 31 tahun. Rata-rata jumlah anggota keluarga petani adalah 3 orang. Luas lahan petani responden terbanyak adalah petani dengan luas lahan kurang dari 0,50 hektar dengan jumlah petani sebanyak 25 orang. Jumlah petani dengan luas lahan 0,6-1,00 hektar adalah 5 orang atau. Luas lahan rata-rata 
petani padi sawah di Kecamatan Cawas Kabupaten Klaten adalah 0,38 Ha.

\section{Biaya, Penerimaan, dan Pendapatan Usahatani Padi Sawah di Kecamatan Cawas Kabupaten Klaten}

Usahatani adalah himpunan dari sumbersumber alam yang terdapat di tempat itu yang diperlukan untuk produksi pertanian seperti tubuh tanah dan air, perbaikan-perbaikan yang telah dilakukan atas tanah itu, sinar matahari, bangunan-bangunan yang didirikan diatas tanah dan sebagainya. Usahatani dapat berupa usaha bercocok tanam atau memelihara ternak (Mubyarto, 1986).

Rata-rata biaya, penerimaan, dan pendapatan usahatani padi sawah di Kecamatan Cawas Kabupaten Klaten dapat dilihat pada Tabel 1. Biaya usahatani merupakan biaya yang dikeluarkan oleh petani untuk melakukan usahatani padi sawah. Pada penelitian usahatani padi sawah ini konsep biaya yang digunakan adalah biaya mengusahakan yang dihitung dengan menjumlahkan biaya alat-alat luar dan upah tenaga kerja keluarga. Benih merupakan faktor yang perlu diperhatikan dalam usahatani padi sawah. Benih dengan kualitas yang baik akan mempengaruhi produksi padi sawah. Biaya rata-rata yang dikeluarkan oleh petani untuk membeli benih yaitu Rp 674.125/Ha. Benih yang ditanam oleh petani yaitu benih padi dengan varietas IR 64. Rata-rata biaya yang digunakan untuk mengusahakan usahatani padi sawah adalah Rp 14.543.253/Ha.

Biaya untuk mengusahakan dalam usahatani padi sawah terdiri dari biaya sarana produksi, biaya tenaga kerja luar, biaya tenaga kerja dalam, penyusutan alat, dan biaya lainlain. Rata-rata biaya sarana produksi yang dikeluarkan oleh petani padi sawah sebesar Rp 2.368.182/Ha. Biaya sarana produksi dalam usahatani padi sawah terdiri dari biaya benih, biaya pupuk, dan biaya pestisida.

Tabel 1. Rata-rata Biaya, Penerimaan, dan Pendapatan Usahatani Padi Sawah di Kecamatan Cawas Kabupaten Klaten Per Ha

\begin{tabular}{|c|c|c|c|c|}
\hline No & Uraian & Jumlah & Biaya (Rp) & Persentase $(\%)$ \\
\hline 1 & Benih $(\mathrm{Kg})$ & 67 & 674.125 & 4,64 \\
\hline \multirow[t]{7}{*}{2} & Pupuk & & & \\
\hline & a. Pupuk Organik (Kg) & 85 & 42.440 & 0,29 \\
\hline & b. Pupuk Urea (Kg) & 231 & 455.369 & 3,13 \\
\hline & c. Pupuk NPK (Kg) & 276 & 645.493 & 4,44 \\
\hline & a. SP-36 (Kg) & 72 & 166.058 & 1,14 \\
\hline & b. ZA $(\mathrm{Kg})$ & 98 & 153.814 & 1,06 \\
\hline & c. $\mathrm{KCL}(\mathrm{Kg})$ & 9 & 23.593 & 0,16 \\
\hline \multirow[t]{6}{*}{3.} & Pestisida & & & \\
\hline & a. $\quad$ Regent $(\mathrm{ml})$ & 43 & 25.219 & 0,17 \\
\hline & b. Fastac (gram) & 381 & 57.188 & 0,39 \\
\hline & c. Score $(\mathrm{ml})$ & 22 & 13.329 & 0,09 \\
\hline & d. Dupont Accapela (ml) & 102 & 99.508 & 0,68 \\
\hline & e. Heksa $(\mathrm{ml})$ & 86 & 12.046 & 0,08 \\
\hline \multirow[t]{3}{*}{4.} & Tenaga Kerja (HKP) & & & \\
\hline & a. Dalam Keluarga & 90,08 & 6.755 .923 & 46,45 \\
\hline & b. Luar Keluarga & 28,56 & 1.830 .127 & 12,58 \\
\hline 5. & Penyusutan Alat (Rp) & & 79.759 & 0,55 \\
\hline \multirow[t]{5}{*}{6.} & Biaya Lain-lain & & & \\
\hline & a. Traktor & & 1.051 .224 & 7,23 \\
\hline & b. Threser & & 2.394 .744 & 16,47 \\
\hline & c. Pajak Tanah & & 63.295 & 0,44 \\
\hline & Total Biaya Mengusahakan & & 14.543 .253 & 100,00 \\
\hline 7. & Penerimaan & & 22.814 .234 & \\
\hline 8. & Pendapatan Bersih & & 8.270 .981 & \\
\hline
\end{tabular}

Sumber : Analisis Data Primer, 2017 
Tabel 2. Hasil Analisis Regresi Faktor-Faktor Yang Mempengaruhi Pendapatan Usahatani Padi Sawah di Kecamatan Cawas Kabupaten Klaten dengan menggunakan SPSS 22

\begin{tabular}{|c|c|c|c|c|}
\hline Variabel & Koefisien Regresi & Standart Error & t-hitung & t-tabel \\
\hline (Constant) & $-18149600,016$ & 3060435,054 & $-5,930$ & 2,109 \\
\hline Umurns $^{\text {ns }}$ & $-19624,006$ & 12076,105 & $-1,625$ & 2,109 \\
\hline Pendidikann ${ }^{\text {ns }}$ & 30408,024 & 24294,860 & 1,252 & 2,109 \\
\hline Pengalaman ${ }^{\text {ns }}$ & 1523,430 & 5786,283 & ,263 & 2,109 \\
\hline Jumlah Tanggungan Keluarga ${ }^{\text {ns }}$ & $-169537,727$ & 125729,488 & $-1,348$ & 2,109 \\
\hline Produktivitas TK** & 70552,862 & 16756,007 & 4,211 & 2,109 \\
\hline Biaya Pupuk ${ }^{\text {ns }}$ &, 558 &, 651 &, 858 & 2,109 \\
\hline Biaya Pestisida** & $-2,139$ & ,969 & $-2,208$ & 2,109 \\
\hline Harga Jual** & 3276,817 & 757,103 & 4,328 & 2,109 \\
\hline $\begin{array}{l}\text { Jumlah Anggota Keluarga Yang } \\
\text { Aktif Usahatani }^{\text {ns }}\end{array}$ & 316739,215 & 307795,337 & 1,029 & 2,109 \\
\hline Produktivitas Lahan** & 582,803 & 178,219 & 3,270 & 2,109 \\
\hline Biaya Traktor** & 7,146 & 1,051 & 6,796 & 2,109 \\
\hline Dummy Jenis Irigasi ${ }^{\mathrm{ns}}$ & $-154131,725$ & 235470,104 &,- 655 & 2,109 \\
\hline R-Square & ,945 & & & \\
\hline F-hitung & $\mathbf{2 4 , 5 1 8} * *$ & & & \\
\hline Durbin-Watson & 2,768 & & & \\
\hline
\end{tabular}

Sumber: Analisis Data Primer, 2017

Keterangan :

** : berpengaruhnyatapadatingkatkepercayaan $95 \%$.

ns $\quad$ : non signifikan (tidak berpengaruh nyata).

Rata-rata biaya tenaga kerja luar yang dikeluarkan oleh petani sebesar $\mathrm{Rp}$ 1.830.127/Ha. Biaya tenaga kerja luar dibutuhkan petani pada saat penanaman padi sawah. Rata-rata biaya penyusutan alat yang dikeluarkan oleh petani dalam satu kali musim tanam padi adalah Rp 79.759/Ha. Rata-rata biaya lain-lain yang dikeluarkan petani padi sawah yaitu Rp. 3.509.263/Ha. Rata-rata biaya tenaga kerja dalam yang dikeluarkan oleh petani sebesar Rp 6.755.923/Ha. Tenaga kerja dalam terdiri dari petani, istri, dan anak petani.

Penerimaan usahatani padi sawah didapatkan dari penjualan hasil produksi. Hasil produksi usahatani padi sawah yang dijual berupa gabah kering panen. Rata-rata penerimaan usahatani padi sawah dalam satu kali musim tanam sebesar Rp 22.814.234/Ha. Rata-rata hasil produksi usahatani padi sawah dalam satu kali musim tanam yang berupa gabah kering panen adalah $6.468 \mathrm{Kg} / \mathrm{Ha}$. Ratarata harga jual gabah kering panen yang berlaku di daerah penelitian sebesar Rp 3.530.

Pendapatan usahatani padi sawah merupakan selisih antara penerimaan dan semua biaya yang dikeluarkan oleh petani untuk usahatani. Pendapatan bersih petani merupakan selisih penerimaan dikurangi dengan total biaya mengusahakan. Rata-rata pendapatan petani padi sawah dalam satu kali musim tanam di Kecamatan Cawas Kabupaten Klaten sebesar Rp 8.270.981.

\section{Faktor-Faktor Yang Mempengaruhi Pendapatan Usahatani Padi Sawah.}

Faktor-faktor yang mempengaruhi pendapatan usahatani padi sawah di Kecamatan Cawas Kabupaten Klaten ditunjukkan oleh model regresi linier berganda yang dihasilkan dari analisis regresiyang dilakukan. Faktor-faktor yang dimasukkan kedalam persamaan adalah umur, pendidikan, pengalaman, jumlah tanggungan keluarga, produktivitas tenaga kerja, biaya pupuk, biaya pestisida, harga jual, jumlah anggota keluarga yang aktif usahatani, produktivitas lahan, biaya traktor, dan jenis irigasi. Hasil analisis regresi faktor-faktor yang mempengaruhi pendapatan usahatani padi sawah di Kecamatan Cawas Kabupaten Klaten dapat dilihat pada Tabel 2. Berdasarkan Tabel 2 dapat diketahui nilai konstanta dan koefisien dari variabel yang digunakan dalam penelitian, sehingga diperoleh persamaan sebagai berikut :

$\mathrm{Y}=-18149600,016-19624,006 \mathrm{X}_{1}+$ $30408,024 \mathrm{X}_{2}+1523,430 \mathrm{X}_{3}-$ $169537,727 \mathrm{X}_{4}+70552,862 \mathrm{X}_{5}+0,558 \mathrm{X}_{6^{-}}$ $2,139 \mathrm{X}_{7}+3276,817 \mathrm{X}_{8}+316739,215 \mathrm{X}_{9}+$ $582,803 \mathrm{X}_{10}+7,146 \mathrm{X}_{11}-154131,725 \mathrm{D}_{1}$ 
Hasil uji determinasi $\left(\mathrm{R}^{2}\right)$ dapat diketahui bahwa nilai $R$ Square sebesar 0,945 atau $94,5 \%$. Hal ini menunjukkan bahwa varian variabel pendapatan usahatani padi sawah dapat dijelaskan oleh variabel umur, pendidikan, pengalaman, jumlah tanggungan keluarga, produktivitas tenaga kerja, biaya pupuk, biaya pestisida, harga jual, jumlah anggota keluarga yang aktif usahatani, produktivitas lahan, biaya traktor, dan jenis irigasi sebesar 94,5\%. Sisanya sebesar 5,5\% dipengaruhi oleh variabel lain di luar model.

Hasil analisis uji $\mathrm{F}$ menunjukkan nilai F-hitung lebih besar daripada nilai F-tabel pada tingkat kepercayaan $95 \%$ yaitu 24,518 (F tabel $\alpha=0,05=2,38)$. Hal ini menunjukkan bahwa Ho ditolak dan $\mathrm{H}_{1}$ diterima, yang berarti variabel umur, pendidikan, pengalaman, jumlah tanggungan keluarga, produktivitas tenaga kerja, biaya pupuk, biaya pestisida, harga jual, jumlah anggota keluarga yang aktif usahatani, produktivitas lahan, biaya traktor, dan jenis irigasi secara bersama-sama berpengaruh nyata terhadap pendapatan usahatani padi sawah di Kecamatan Cawas Kabupaten Klaten.

Uji Keberartian Koefisien Regresi (Uji t) menunjukkan bahwa nilai $\mathrm{t}$ hitung variabel umur negatif 1,625 kurang dari t-tabel $(1,625 \leq$ 2,109), yang artinya $\mathrm{Ho}$ diterima dan $\mathrm{H}_{1}$ ditolak. Hal ini dapat diartikan bahwa variabel umur secara individu tidak berpengaruh nyata terhadap pendapatan usahatani padi sawah. Umur tidak berpengaruh nyata terhadap pendapatan usahatani padi sawah dikarenakan perbedaan usia petani tidak mempengaruhi semangat kerja petani. Petani dengan usia muda ataupun tua, sama-sama memiliki semangat kerja yang tinggi dalam melakukan usahatani padi sawah. Petani muda ataupun tua samasama masih mampu dan aktif dalam menjalankan usahatani padi sawah.

Nilai t hitung variabel pendidikan 1,252 lebih kecil dari t- tabel $(1,252 \leq 2,109)$, yang artinya $\mathrm{Ho}$ diterima dan $\mathrm{H}_{1}$ ditolak. Hal ini berarti pendidikan secara individu tidak berpengaruh nyata terhadap pendapatan usahatani padi sawah. Pendidikan tidak berpengaruh nyata terhadap pendapatan usahatani padi sawah, hal ini dikarenakan sebagian besar petani berpendidikan rendah dan banyak petani yang tidak sekolah.

Nilai t hitung variabel pengalaman 0,263 kurang dari t-tabel $(0,263 \leq 2,109)$, yang artinya
Ho diterima dan $\mathrm{H}_{1}$ ditolak. Hal ini berarti pengalaman secara individu tidak berpengaruh nyata terhadap pendapatan usahatani padi sawah. Pengalaman petani tidak berpengaruh nyata terhadap pendapatan, hal ini dikarenakan petani kurang belajar dari pengalaman. Petani cenderung takut untuk mencoba hal-hal baru. Petani dengan pengalaman usahatani yang sudah lama cenderung kolot, hal tersebut berbeda dengan petani yang memiliki pengalaman usahatani masih baru. Petani yang baru memulai usahatani cenderung ingin mencoba hal-hal yang baru untuk usahatani padi sawah yang lebih baik.

Nilai $t$ hitung variabel jumlah tanggungan keluarga negatif 1,348 kurang dari t-tabel $(1,348 \leq 2,109)$, yang artinya Ho diterima dan $\mathrm{H}_{1}$ ditolak. Hal ini berarti jumlah tanggungan keluarga tidak berpengaruh nyata terhadap pendapatan usahatani padi sawah. Jumlah tanggungan keluarga tidak berpengaruh nyata terhadap pendapatan usahatani padi sawah, hal ini dikarenakan jumlah tanggungan keluarga petani padi sawah rata-rata hanya 2 orang, yaitu istri petani dan seorang anak. Sebagian anak-anak petani sudah merantau dan bekerja di luar sektor pertanian.

Nilai $\mathrm{t}$ hitung variabel produktivitas tenaga kerja sebesar 4,211 lebih besar dari ttabel $(4,211>2,109)$, yang artinya Ho ditolak dan $\mathrm{H}_{1}$ diterima. Hal ini berarti variabel produktivitas tenaga kerja secara individu berpengaruh nyata terhadap pendapatan usahatani padi sawah. Nilai koefisien regresi variabel produktivitas tenaga kerja positif $70.552,862$ sehingga apabila terjadi penambahan satu satuan produktivitas tenaga kerja, maka akan meningkatkan pendapatan petani padi sawah sebesar Rp 70.552,862. Produktivitas tenaga kerja berpengaruh nyata terhadap pendapatan, hal ini dikarenakan jika produktivitas tenaga kerja tinggi, maka pendapatan yang diterima oleh petani juga tinggi. Penggunaan bantuan mesin dapat meningkatkan efisiensi tenaga kerja. Dengan bantuan mesin, maka tenaga kerja yang dicurahkan lebih sedikit sehingga pembagi dari jumlah produksi akan semakin kecil dan mendapatkan nilai produktivitas yang lebih besar.

Nilai thitung variabel biaya pupuk 0,858 lebih kecil dari t-tabel $(0,858 \leq 2,109)$, yang artinya $\mathrm{Ho}$ diterima dan $\mathrm{H}_{1}$ ditolak. Hal ini 
berarti variabel biaya pupuk secara individu tidak berpengaruh nyata terhadap pendapatan usahatani padi sawah. Biaya pupuk tidak berpengaruh nyata terhadap pendapatan usahatani, hal ini dikarenakan semakin tinggi biaya yang dikeluarkan petani untuk membeli pupuk, mengakibatkan bertambahnya biaya. Semakin banyak biaya yang dikeluarkan oleh petani maka pendapatan yang diterima semakin sedikit.

Nilai $\mathrm{t}$ hitung variabel biaya pestisida negatif 2,208 lebih dari t tabel $(2,208>2,109)$, yang artinya Ho ditolak dan $\mathrm{H}_{1}$ diterima. Hal ini dapat diartikan variabel biaya pestisida secara individu berpengaruh nyata terhadap pendapatan usahatani padi sawah. Nilai koefisien regresi variabel $-2,139$ sehingga apabila terjadi penambahan satu rupiah biaya pestisida, maka akan menurunkan pendapatan petani padi sawah sebesar Rp 2,139. Biaya pestisida secara individu berpengaruh nyata terhadap pendapatan usahatani padi sawah, hal ini dikarenakan semakin tinggi biaya yang dikeluarkan petani untuk membeli pestisida sehingga mengakibatkan bertambahnya biaya. Semakin banyak biaya yang dikeluarkan oleh petani maka pendapatan yang diterima semakin sedikit. Tidak semua petani menggunakan pestisida untuk mengendalikan hama dan penyakit tanaman padi. Pestisida hanya digunakan apabila serangan hama dan penyakit tanaman sudah melebihi batas ambang ekonomi.

Nilai t hitung variabel harga jual 4,328 lebih besar dari t- tabel $(4,328>2,109)$, yang artinya Ho ditolak dan $\mathrm{H}_{1}$ diterima. Hal ini berarti variabel harga jual secara individu berpengaruh nyata terhadap pendapatan usahatani padi sawah. Nilai koefisien regresi variabel positif $3.276,817$ sehingga apabila terjadi penambahan satu rupiah harga jual, maka akan meningkatkan pendapatan petani padi sawah sebesar Rp 3.276,817. Harga jual secara individu berpengaruh nyata terhadap pendapatan usahatani padi sawah, hal ini dikarenakan apabila harga jual gabah kering panen tinggi pendapatan yang diterima petani tinggi dan begitu pula sebaliknya. Jika harga gabah kering panen rendah, maka pendapatan yang diterima petani juga rendah.

Nilai t hitung variabel jumlah anggota keluarga yang aktif usahatani1,029 kurang dari t-tabel $(1,029 \leq 2,109)$, yang artinya $\mathrm{Ho}$ diterima dan $\mathrm{H}_{1}$ ditolak. Hal ini berarti jumlah anggota keluarga yang aktif usahatani tidak berpengaruh nyata terhadap pendapatan usahatani padi sawah. Jumlah anggota keluarga yang aktif usahatani tidak berpengaruh nyata terhadap pendapatan usahatani padi sawah, hal ini dikarenakan jumlah anggota keluarga yang aktif usahatani padi sawah rata-rata hanya 1 orang, yaitu istri petani.

Nilai $t$ hitung variabel produktivitas lahan 3,270 lebih besar dari t-tabel (3,270> 2,109), yang artinya Ho ditolak dan $\mathrm{H}_{1}$ diterima. Hal ini berarti variabel produktivitas lahan secara individu berpengaruh nyata terhadap pendapatan usahatani padi sawah. Nilai koefisien regresi variabel produktivitas lahan positif 582,803 sehingga apabila terjadi penambahan satu satuan, maka akan meningkatkan pendapatan petani padi sawah sebesar Rp582,803. Produktivitas lahan sesuai dengan kemampuan lahan untuk menerima input guna menghasilkan output. Faktor produktivitas lahan berpengaruh nyata terhadap pendapatan, hal ini dikarenakan jika produktivitas lahan tinggi, maka pendapatan yang diterima oleh petani juga tinggi.

Nilai t hitung variabel biaya pestisida negatif 6,796 lebih dari t-tabel $(6,796>2,109)$, yang artinya $\mathrm{Ho}$ ditolak dan $\mathrm{H}_{1}$ diterima. Hal ini dapat diartikan variabel biaya traktor secara individu berpengaruh nyata terhadap pendapatan usahatani padi sawah. Nilai koefisien regresi variabel 7,146 sehingga apabila terjadi penambahan satu rupiah biaya traktor, maka akan meningkatkan pendapatan petani padi sawah sebesar Rp 7,146. Biaya traktor secara individu berpengaruh nyata terhadap pendapatan usahatani padi sawah, hal ini dikarenakan dengan adanya mesin traktor, maka pengolahan tanah jadi lebih efektif dan efisien. Dengan adanya traktor, maka tenaga kerja yang dibutuhkan untuk olah tanah lebih sedikit dan menghemat biaya.

Nilai t hitung variabel dummy jenis irigasi negatif 0,655 kurang dari t-tabel $(0,655$ $\leq 2,109$ ), yang artinya Ho diterima dan $\mathrm{H}_{1}$ ditolak. Hal ini berarti variabel dummy jenis irigasi tidak berpengaruh nyata terhadap pendapatan usahatani padi sawah. Dummy jenis irigasi (0 : Lainnya, 1 : Teknis) tidak berpengaruh nyata terhadap pendapatan usahatani dikarenakan pada musim tanam pertama petani padi sawah tidak mengeluarkan 
biaya untuk irigasi karena air curah hujan tinggi sehingga air hujan sudah mencukupi untuk pertumbuhan dan perkembangan tanaman padi sawah. Iuran irigasi dilakukan petani pada musim tanam kedua (musim kemarau).

\section{KESIMPULAN DAN SARAN}

\section{Kesimpulan}

Berdasarkan hasil penelitian mengenai Analisis Faktor-faktor yang Mempengaruhi Pendapatan Usahatani Padi Sawah di Kecamatan Cawas Kabupaten Klaten, maka dapat diambil kesimpulan bahwa biaya mengusahakan usahatani padi sawah per hektar adalah $\mathrm{Rp}$ 14.543.253per musim tanam, Penerimaan usahatani padi sawah perhektar adalah Rp 22.814.234 per musim tanam, dan pendapatan yang diterima oleh petani padi sawah per hektar adalah Rp 8.270.981 per musim tanam.

Faktor-faktor berupa produktivitas tenaga kerja, biaya pestisida, harga jual, produktivitas lahan, dan biaya traktor berpengaruh nyata terhadap pendapatan usahatani padi sawah. Faktor-faktor berupa umur, pendidikan, pengalaman, jumlah tanggungan keluarga, biaya pupuk, jumlah anggota keluarga yang aktif usahatani dan jenis irigasi tidak berpengaruh nyata terhadap pendapatan usahatani.

\section{Saran}

Berdasarkan hasil penelitian disarankan untuk memberikan pendidikan dan pelatihan untuk meningkatkan produktivitas tenaga kerja petani padi sawah, penyuluhan mengenai tata cara menyemprot yang baik dan dosis penggunaan pestisida perlu dilakukan agar dosis pemakaian pestisida yang tepat. Selain itu sebaiknya dibuat suatu kebijakan agar harga gabah saat panen stabil dan pendapatan yang diterima oleh petani tinggi, petani disarankan menggunakan traktor untuk melakukan olah tanah agar lebih efisien karena tidak membutuhkan tenaga kerja yang dalam jumlah banyak, dan petani harus lebih menjaga kondisi tanah dengan menggunakan pupuk organik dan pupuk kimia secara berimbang.

\section{DAFTAR PUSTAKA}

Lumintang, F.M. 2013. Analisis Pendapatan Petani Padi Di Desa Teep Kecamatan Langowan Timur. Jurnal EMBA 991 (1) 3: 991-998.

Mubyarto. 1986. Pengantar Ekonomi Pertanian. LP3ES. Jakarta.

Nababan, C.D. 2009. Analisis Faktor-faktor yang mempengaruhi pendapatan petani jagung di Kecamatan Tiga Binanga Kabupaten Karo. Universitas Sumatera Utara. Medan.

Purnamaningsih, R. 2006. Induksi Kalus dan Optimasi Regenerasi Empat Varietas Padi Melalui Kultur In Vitro. $J$. Agrobiogen 2(2):74-80.

Rahim, A. dan Diah R. D. H. 2007. Pengantar, Teori, dan Kasus Ekonomika Pertanian. Cetakan Kedua. Penebar Swadaya. Jakarta.

Sukirno, S. 2000. Mikro Ekonomi Modern: Perkembangan Pemikiran dari klasik sampai Keynesian Baru, Edisi 1. PT Raja Grafindo. Jakarta

Suratiyah, K. 2015. Ilmu Usahatani. Penebar Swadaya. Jakarta. 